\title{
Pediyatrik Popülasyonda COVID-19 Pandemisi
}

\section{COVID-19 Pandemia in Pediatric Population}

\author{
Özge Kaba ${ }^{1}\left(\mathbb{C}\right.$, Ayper Somer $^{1}(\mathbb{C}$
}

${ }^{1}$ istanbul Üniversitesi, İstanbul Tıp Fakültesi, Çocuk Enfeksiyon Hastalıkları Bilim Dalı, İstanbul, Türkiye

ORCID ID: Ö.K. 0000-0002-8381-3255; A.S. 0000-0002-7827-1113

Attf/Citation: Kaba O, Somer A. Pediyatrik popülasyonda COVID-19 pandemisi. Çocuk Dergisi - Journal of Child 2020;20(2):66-71. https://doi.org/10.26650/jchild.2020.2.763279

öz

Bugüne kadar hem hayvan hem de insanlarda enfeksiyon oluşturduğu bilinen koronavirus ailesine, 2019 yılı sonlarında, kümelenmiş atipik pnömoni vakalarında tanımlanan yeni tip bir koronavirus eklenmiştir. Pandemi ilanına sebep olan bu virus özellikle ileri yaş ve komorbid hastalı̆ı̆ olan erişkin yaş grubunda etkili olmuştur. Çocukluk çağında çoğunlukla kendini hafif hastalık olarak gösteren bu etken nadir de olsa kritik hastalık tablosu meydana getirmektedir. Ortaya çıktığı andan itibaren destek tedavi uygulamalarının yanında çeşitli antiviral tedaviler denenmiştir. Ağılıklı olarak erişkin yaş grubunda uygulanan bu tedavilerin kısmen etkili olduğu bildirilse de virusa spesifik tedavi seçeneği henüz mevcut değildir. İlaç ve aşı geliştirme çalışmaları bir umut ışığı oluştursa da enfeksiyondan kaçınabilmenin şimdilik tek yolu korunma önlemlerine uymaktan geçer.

Anahtar Kelimeler: SARS-CoV-2, çocuk, COVID-19 hastalığı

\section{ABSTRACT}

A new type of coronavirus, identified in clustered atypical pneumonia cases, was added to the family of coronavirus known to cause infection in both animals and humans to date. This virus, which caused the announcement of pandemic, was especially effective in the adult age group with advanced age and comorbid disease. This factor, which generally manifests itself as a mild disease in childhood, rarely creates a critical disease picture. Various antiviral therapies have been tried as well as supportive treatments since its emergence. Although it is reported that these treatments, which are mostly administered in the adult age group, are partially effective, virusspecific treatment options are not yet available. Although drug and vaccine development efforts create a glimmer of hope, the only way to avoid infection is to follow the protection measures for now.

Keywords: SARS-CoV-2, child, COVID-19 disease

\section{GiRiş}

Coronaviridae ailesi ve Orthocoronavirinae alt ailesine ait olan koronaviruslar hem insanlarda hem de hayvanlarda pek çok enfeksiyon ile ilişkilendirilmiştir. İlk defa 1937 yılında kuşlarda görülen bronşit vakalarından izole edilmişlerdir (1). 1960’। yıllarda insan koronavirus (HCoV)-229E ve HcoV-OC43'ün gösterilmesiyle ile genişleyen aileye, 2000'li yıllardan itibaren HcoV-NL63, HcoV-HKU1 de katılmış olup, bu 4 virüs insanlarda soğuk algınlığı ve üst solunum yolu enfeksiyonlarının sık görülen patojenlerinden olmuştur (2). 2003 yılında tanımlanan ciddi akut solunum yolu sendromu koronavirüsü (Severe Acute Respiratory Syndrome Coronavirus, SARS-CoV) ile 2012 yılında tanımlanan Ortadoğu respiratuvar sendrom koronavirusu (Middle East Respiratory Syndrome Coronavirus, MERS- CoV) ise meydana getirdikleri ciddi pnömoni tabloları ve yüksek fatalite hızı ile dikkat çeken beta koronavirüslerdendir (3).
2019 yılı Aralık ayı sonlarına doğru Çin'in Wuhan şehrinde benzer özellikler gösteren kümelenmiş atipik pnömoni vakaları saptanmıştr. İzolasyonu ile birlikte yeni tip bir koronavirüs olduğu anlaşılan bu virüsün kaynağının, Wuhan şehrindeki Huanan deniz ürünleri marketinde satılan hayvanlar olduğu düşünülmektedir (4). 5 Ocak 2020'de Dünya Sağlık Örgütü (World Health Organization, WHO) tarafindan dünyaya duyurulan bu tablo, Çin'in diğer şehirleri ile Çin dışındaki ülkelere de yayılmaya devam etmiştir. Ocak ayı sonlarına doğru global bir sorun haline gelen hastalık, 11 Şubat 2020 tarihinde Coronavirüs hastalığı 19 (Coronavirus disease 19, COVID 19) olarak tanımlanmıştır (5). İlk çocuk vaka 20 Ocak 2020'de Çin'den bildirilmiştir (6). Ülkemizde ilk vakanın görüldüğü 11 Mart 2020 tarihi aynı zamanda WHO tarafindan pandeminin ilan edildiği tarihtir (7). 01 Temmuz 2020 tarihi itibariyle 216 ülkeden bildirilen bu viral enfeksiyon, 502,278 kişinin ölümüne ve 10,117,687 kişinin de enfekte olmasına yol açmıştır (8). 


\section{VIROLOJI VE PATOGENEZ}

Koronavirüsler zarflı, segmentsiz, tek zincirli, pozitif polariteli ve tanımlanabilen en büyük viral RNA'ya sahip RNA virüsleridir. İsimlendirmede yüzeylerinde bulunan dikensi glikoprotein yapılarının "taç" şekline benzerliği etkili olmuştur (3). Alfa, beta, gama ve delta cinslerine ayrılan koronavirüslerden, insanları sadece alfa ve beta koronavirüslerin enfekte ettiği bilinmektedir (9). Cinslerine ve alt gruplarına göre koronavirüslerin filogenetik dağılımı Şekil 1'de gösterilmektedir.

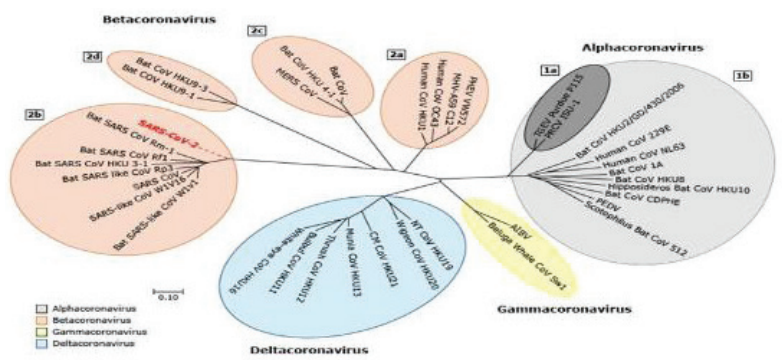

Şekil 1: Koronavirüslerin filogenetik dağılımı (10).

Fare, tavuk, hindi, domuz, köpek, kedi, yarasa, tavşan, at, sığır, deve gibi pek çok farklı konağı olan bu virus, büyük RNA'sı ve hızlı replikasyon yeteneği ile mutasyonların hedefi olmaktadır. Günümüze kadar görülmüş olan örnekleri, Çin'de Minsk kedilerinden orijin alan SARS ile Suudi Arabistan'da develerden orijin alan MERS hastalığıdır. Yapılan dizilemeler ile yeni tip koronavirüsün SARS-CoV'a yüzde seksenin üzerinde bir oranla benzerlik gösterdiği ortaya konmuş ve bu yeni tip koronavirüs SARS-CoV-2 olarak nihai adına kavuşmuştur (11).

Diziliminin yanında SARS-CoV ile bir başka ortak noktası ise hücreye tutunma ve penetrasyon basamaklarında anjiyotensin dönüştürücü enzim (ACE) 2'yi kullanmasıdır. Bu reseptörler akciğer, kalp, ileum, böbrek ve mesane endotel hücrelerinde de eksprese edilir (12). Penetrasyon sonrasında viral RNA hücre içine girer ve biyosentez basamağında virüse ait dikensi (spike, S), membran (M), zarf (envelope, E) ve nükleokapsid (N) proteini gibi yapısal proteinler üretilir (13). Matürasyon basamağının da tamamlanması sonrasında salınım ile virüs yaşamını sürdürür.

Virüsün hücreye girmesi ile T hücrelerine dentritik hücre ve makrofajlar aracılı antijen sunumu başlar. Uyarılan T hücreleri; CD4+ T hücreleri aracılığıyla $B$ hücrelerinin aktivasyonu ve virüs spesifik antikor üretimini, CD8+ T hücreleri aracılığıyla ise enfekte hücrelerin öldürülmesini sağlar (14). Ayrıca reseptör hücrelerinin endotel hücrelerinde bulunmasının bir sonucu olarak tromboz dengesi bozulur ve hiperkoagülabiliteye eğilim artar (15). İmmün sistemin interlökin (IL) 6, IL 1, TNF- $\alpha$, interferon aracılı olarak meydana gelen suprafizyolojik pro-inflamatuvar cevabı sitokin firtınası ile sitokin firtınası ise akut solunum sıkıntisı sendromu (Acute Respiratory Distress Syndrome, ARDS) ve çoklu organ yetersizliği tablosu ile sonlanabilir (16).

Yukarıda tarif edilen immün mekanizmaların pediatrik yaş grubunda erişkine göre farklı işlemesi nedeniyle hastalık tablosunun daha hafif seyrettiği düşünülmektedir. Doğal immünitenin tam gelişmemiş olması, ACE2 reseptörlerinin işlerliğinin kısıtlı olması, sık geçirilen diğer viral enfeksiyonlar ile edinilen çapraz koruma, mortaliteyi arttrabilecek risk faktörlerinin olmayışının hastalığın hafif geçirilmesi noktasında etkili olduğu düşünülmektedir (17).

\section{EPIDEMIYOLOJi}

Güncel verilere göre Antarktika kıtası hariç tüm kıtalarda toplam 216 ülkede görüldüğü bildirilen salgının, Çin'den sonra ikincil merkezi Mart ayından itibaren Avrupa ve Amerika Birleşik Devletleri olmuştur. Bulaşın; enfekte kişinin öksürme, hapşırma ve hatta konuşma sırasında saçtı̆ı solunum sekresyonları veya bu sekresyonların düştüğü yüzeylere temas sonrası müköz membranlara dokunma ile direkt bulaştğı gösterilmiştir (18). Aerosol oluşan ortamlarda bulaş riskinin artabileceği tahmin edildiğinden aerosolizasyon işlemlerinde gerekli tedbirlerin alınması önerilmektedir (19). SARS-CoV-2 virüsü kan, gaita, idrar, göz yaşı gibi vücut sıvılarında da saptanmıştır. Fekal-oral yolun yayılmada etkin

Tablo 1: Faklı koronavirüs tiplerinin yüzeylerde kalabilme süresi (25).

\begin{tabular}{lllll}
\hline Yüzey tipi & Virus tipi & Viral titre & Sıcaklık & Persistans süresi \\
\hline Çelik & HCoV-229E & $10^{6}$ & $21^{\circ} \mathrm{C}$ & 5 gün \\
& MERS-CoV & $10^{5}$ & $20^{\circ} \mathrm{C}$ sa \\
Alüminyum & HCoV-229E & $5 \times 10^{3}$ & $21^{\circ} \mathrm{C}$ & $2-8$ sa \\
& HCoV-OC 43 & $5 \times 10^{3}$ & $21^{\circ} \mathrm{C}$ & $2-8$ sa \\
Tahta & SARS-CoV & $10^{5}$ & OS gün \\
Kağıt & SARS-CoV(P9) & $10^{5}$ & OS & $4-5$ gün \\
Cam & SARS-CoV(P9) & $10^{5}$ & OS gün \\
& HCoV-229E & $10^{3}$ & $21^{\circ} \mathrm{C}$ & 5 gün \\
Plastik & SARS-CoV(P9) & $10^{5}$ & OS gün \\
& HCoV-229E & $10^{7}$ & OS & $2-6$ gün \\
Seramik & HCoV-229E & $10^{3}$ & $21^{\circ} \mathrm{C}$ & 5 gün \\
Teflon & HCoV-229E & $10^{3}$ & $21^{\circ} \mathrm{C}$ & 5 gün
\end{tabular}

MERS-CoV: Ortadoğu respiratuvar sendrom koronavirüsü (Middle East Respiratory Syndrome Coronavirus); HCoV: İnsan koronavirüsü (Human coronavirus); SARSCoV: Ciddi akut solunum yolu sendromu koronavirüsü (Severe Acute Respiratory Syndrome Coronavirus); OS: oda sıcaklığı. 
olmadığı düşünülse de tuvalet eğitimi almamış süt çocuğu ve çocuklara da dikkat edilmesi gerektiği vurgulanmaktadır (20). Henüz vertikal bulaşa dair kanıt bulunamamıştır (21).

Hastalığın kuluçka süresi ortalama 5-7 gün arasında olup minimum 2 gün, maksimum 14 gün kadar olabileceği bilinmektedir (22). Semptomların ortaya çıkmasından 1-3 gün önce ve hastalık dönemi boyunca bulaştırıcı olduğu ve virüs saçılım süresinin de hastalık şiddeti ve virüs yükü ile korele olduğu düşünülmektedir (23). Literatürde bildirilmiş olan en uzun saçılım süresi 62 günden fazladır (24). SARS-CoV-2 virüsünün yüzeylerde canlılığını koruyabildiği süre bilinmemekte olup, diğer koronavirüslerin optimum şartlar sağlandığında yüzeylerde 5 güne kadar kalabildiği de bilinmektedir (Tablo 1).

\section{KLINIK BULGULAR}

Bulaşta rolü olduğu düşünülen asemptomatik bireylerin \%40-45 oranında olduğu tahmin edilmektedir (26). Pandemi kontrolünde yapılması önerilen taramalarla semptomatik bireylerin saptanmasının bulaş hızını düşürebileceği öne sürülmektedir. Virüsün çıkış noktası olan Wuhan'da SARS-CoV-2 pozitif saptanan 171 çocuk vaka değerlendirildiğinde yaklaşık \%16'sının asemptomatik olduğu görülmüştür. Yine Çin'e ait, kanıtlı COVID-19 hastalığı olan 728 çocuk olgunun değerlendirildiği bir başka vaka serisinde vakaların \%55'inin asemptomatik ve hafif hastalık tablosu taşıyan olgular olduğu ortaya konmuştur.

2020 yılı Mart ayı ortalarında yapılan analizler, tüm dünyadaki çocuk vaka oranını \%1-5 olarak belirlemiştir (27). Yakın tarihlerde, Asya ve Avrupa kıtaları ile ülkemizden bildirilen pediatrik vaka oranları \%2'nin altında kalırken, Haziran 2020'de, Amerika Birleşik Devletleri'ndeki oran, \%3.2 olarak duyurulmuştur (28).

Erişkin yaş grubunda olduğu gibi pediayatrik grupta da erkek cinsiyetin ön planda etkilendiği bilinmektedir. Etkilenen yaş grubunun ağırlıklı olarak 5 yaş üzeri olduğu, bunu da 1 yaş alt grubun takip ettiği ve görülen ağır hastalık tablolarının da yine 1 yaş altı grupta olduğu bildirilmiştir (29). Bunun yanında yoksulluk, sağlık hizmetine ulaşım güçlüğü, farklı kuşakların bir arada yaşadığı etnik/ırksal statülerin de fark yaratabileceği ön görülmektedir (30). Ağır hastalık oranı düşük olsa bile kardiyovasküler hastalık, diyabet, obezite, hipertansiyon, kronik akciğer ve böbrek hastalıkları gibi komorbiditelerin varlığı hastalık tablosunu ağılaştırmakta ve artmış mortalite ile ilişkilendirilmektedir (29).

Ateş ve öksürük pediatrik hasta grubunda en sık bildirilen semptomlardır (31). Erişkin yaş grubuna benzerlik gösteren bu semptomların yanı sıra halsizlik, burun akıntısı, burun tıkanıklığı, yaygın kas ağrısı, tat ve koku duyusunda azalma da bildirilen diğer semptomlardır (32). Dong ve ark.'ları (33) tarafindan yapılan bir çalışmada, SARS-CoV-2 pozitif hastalar semptom varlığı, fizik muayene bulgusu, patolojik görüntüleme bulgusu varlığına göre değerlendirilmiştir. Mevcut bulgularına göre gruplandırılan hastalarda, klinik progresyonu ifade eden asemptomatik, hafif, orta, ciddi ve kritik olmak üzere 5 hastalık evresi tanımlanmıştır (33).

Respiratuvar bulgular olmaksızın ishal, kusma, karın ağrısı gibi belirtilerin görülen yaygın gastrointestinal bulgular olduğu bildirilmiştir (33). Bu durum da mevcut ACE-2 reseptörlerinin ince bağırsakta da bulunması ile açıklanmıştır.

Çok iyi tanımlanmasa da makülopapüler, ürtikeryal, veziküler karakterli döküntüler tarif edilmiştir (34). Şüpheli veya doğrulanmış COVID-19 hastalığı olan çocuk ve genç yetişkin bireylerin sakral bölgelerinde görülen pernio benzeri lezyonlar tanımlanmıştır (35). Görülme sıklığı olarak \%0.2-20.4 arasında geniş bir aralık verilmektedir (36).

Kardiyotropik olmadığı bilinen bu virusun viral miyokardit, hipoksik hasar, stres kardiyomiyopatisi veya sitokin firtnnası gibi mekanizmalarla aritmi, kalp yetersizliği, kardiyojenik şok gibi kardiyak sorunlara yol açabileceği düşünülmektedir (37).

Pediyatrik yaş grubunda, Nisan 2020'de başta Birleşik Krallık olmak üzere, Avrupa, Kanada ve Amerika Birleşik Devletleri'nden inkomplet Kawasaki Sendromu veya toksik şok tablosuna benzer vakaların varlığı bildirildi (38). Patofizyolojisi henüz aydınlatılamamış olan bu tablonun, virusa karşı geliştirilen anormal immün yanıta dayandığı öngörülmektedir. Sitokin salınım sendromu, makrofaj aktivasyon sendromu veya Kawasaki hastalığına benzerliği nedeniyle pediyatrik multisistemik inflamatuvar sendrom, pediatrik hiperinflamatuvar sendrom, pediatrik hiperinflamatuvar şok gibi farklı tanımlamalar yapıımıştır. Mayıs ayı ortalarında Dünya Sağlık Örgütü ve Hastalık Kontrol ve Önleme Merkezi tarafindan benzer kriterlerle tanımlanan bu duruma, Sağlık Bakanlığı'nın güncellenen tedavi rehberinde de yer verilmiştir (Tablo 2).

\section{TANI}

Klinik veya epidemiyolojik bulguların varlığında, kesin tanı koymak amacıyla, hastanın mevcut hastalık tablosuna göre orofarengeal ve nazal sürüntü veya alt solunum yolu aspirasyon örneklemesi yapılmalıdır. Gerçek zamanlı, ters transkriptazpolimeraz zincir reaksiyonu aracılı nükleik asit amplifikasyon testleri gibi virüse ait gen bölgelerinin gösterildiği testlerin, tanıda kullanılması kabul görmüştür. Doğruluğu sistematik olarak değerlendirilmemiş olsa da oldukça spesifik testlerdir (40). Yanlış negatiflik oranı \%5-40 arasında bildirilen bu testin negatif sonuçlanması tanıyı dışlatmaz (41). Klinik şüphenin devam etmesi halinde $24-48$ saat sonra ikinci bir örnekleme yapılması ve mümkünse bu örneğin alt solunum yollarından alınması önerilmektedir.

Serolojik testler ile gösterilebilen SARS-CoV-2 enfeksiyonuna karşı geliştirilen antikorlar geçirilmiş veya geçirilmekte olan hastalık tablosuna işaret eder (42). Sensitivite ve spesifitesi kesin olarak bilinmeyen bu testlerin tek başına tanı koymada veya tanıyı dışlamada rolü yoktur.

Nükleik asit testlerinden daha az duyarlı olduğu bilinen, geçirilmekte olan enfeksiyon tablosuna işaret eden ve bir saatten daha kısa sürede sonuç veren antijen testleri de mevcuttur (43). Güvenlik gerekçeleri nedeniyle viral kültürü önerilmemektedir.

Mikrobiyolojik yöntemlerden sonra tanıda oldukça yardımcı olan bir diğer yöntem görüntülemedir. Erken dönemde normal olabilen direkt grafilere ile karşılaştrıldığında toraksın 
Tablo 2: T.C. Sağlık Bakanlığı COVID-19 (SARS-CoV-2 enfeksiyonu) çocuk hasta yönetimi ve tedavi rehberi. Olgu tanımının sağlanabilmesi için her maddeden istenen sayıda kriterin varlığı gerekmektedir (39).

$10-21$ yaş arasında olmak

224 saatten uzun süren $>38.0^{\circ} \mathrm{C}$ ateş varlığını

3 Laboratuvar tetkiklerinde inflamasyon kanıtı (En az 2 veya daha fazlasının varlığı)

- Artmış C-reaktif protein

- Artmış sedimantasyon

- Artmış fibrinojen

- Artmış prokalsitonin

- Artmış D-dimer

- Artmış ferritin

4 Hastaneye yatış gerektirecek ağır hastalık tablosu

5 Çoklu organ sistem tutulumu (En az 2 veya daha fazlasının varlığı)

- Kardiyovasküler (Şok, yüksek troponin, yüksek BNP, anormal eko bulguları, aritmi)

- Solunum (Pnömoni, ARDS, pulmoner emboli)

- Böbrek (Böbrek yetersizliği)

- Nörolojik (Konvülziyon, inme, aseptik menenjit)

- Hematolojik (Koagülopati, yüksek D-dimer düzeyi)

- Gastrointestinal (Yüksek karaciğer enzimleri, diyare, ileus)

- Dermatolojik (Eritrodermi, mukozit, diğer döküntü)

6 Alternatif başka tanı olmaması (bakteriyel sepsis, enterovirus enfeksiyonu gibi miyokardit ile ilişkili enfeksiyonlar, stafilokoksik veya streptokoksik toksik şok sendromları gibi)

7 Geçirilmiş veya yeni geçirilmekte olan SARS-CoV-2 enfeksiyon kanıtı (Aşağıdakilerden en az birisinin varlığı)

- SARS-CoV-2 RT-PCR pozitifliği

- SARS-CoV-2 seroloji pozitifliği

- SARS-CoV-2 antijen pozitifliği

- Semptomların başlamasından önceki 4 hafta içerisinde SARS-CoV-2 pozitif olgu teması bilgisayarlı tomografisinin (BT) daha duyarlı olduğu bilinmektedir (44). Özellikle alt akciğer alanlarının sıklıkla bilateral ve perifer ağırlıklı tutulduğu bildirilmiştir. Bao ve ark.'larının (45) 2700 hastayı değerlendirdiği sistematik bir derlemede en sık bildirilen anormal özellikler buzlu cam opasiteleri, konsolidasyon, plevral kalınlaşma, interlobüler septal kalınlaşma ve hava bronkogramları olmuştur.

Kesin tanıda rol oynayan herhangi bir laboratuvar parametresi bulunmamakla birlikte lenfopeni, transaminaz yüksekliği, laktat dehidrogenaz yüksekliği, C-reaktif protein, sedimantasyon ve interlökin- 6 gibi akut faz parametrelerinde artı̧ gibi bazı değişimler sık bildirilmiştir (46). Bunun yanında D-dimer artışı, ferritin artışı, lenfopeni varlığı, prokalsitonin artş̧ı gibi değişimlerin varlığı kötü prognostik faktörler olarak belirlenmiştir (47).

\section{TEDAVi}

Tedavide güvenilirlik ve etkinliği kanıtlanmış olan spesifik bir ilaç bulunmamaktadır. Medikal tedavide, riskli hasta grubunda uygulanan ve yararlı olduğuna dair çeşitli verilerin yayınlandığı aday ilaçların destek tedavinin yanında kullanılabileceği bildirilmiştir. Favipiravir, remdesivir, interlökin-1 ve IL-6 inhibitörleri bunlardan bazılarıdır (48). Daha önceden kullanımı önerilen ve Amerikan İlaç ve Gıda Dairesi (Food and Drug Administration, FDA) tarafindan onaylanan hidroksiklorokin ise potansiyel risklerin daha ağır basması nedeniyle kullanımdan kaldırılmıştır (49).

Pediyatrik yaş grubunda genellikle hafif hastalık tablosunda seyreden bu enfeksiyon nadiren tedavi gereksinimi doğurur. Komorbid hastalığı veya hastaneye yatış ihtiyacı olmayan hasta grubu, ateş kontrolü ve hidrasyon destek tedavileri ile evde izole edilerek izlenebilir. Pnömoni ve buna bağlı solunum sıkıntısının ön planda olduğu durumlarda nazal kanül ile verilen yüksek akımlı oksijen, invazif olmayan mekanik ventilasyon ve gerekirse de invazif mekanik ventilasyon gündeme gelebilir (50). Net bir öneri olmamakla birlikte oksijen ihtiyacı, şok tablosu ile birlikte ciddi ve kritik hastalık durumları ile pediatrik multisistemik inflamatuvar sendrom izlenen seçilmiş hastalarda uygulanmış çeşitli tedaviler literatürde bildirilmiştir (51).

\section{KORUNMA}

Virusa spesifik herhangi bir tedavi bulunmadığından en önemli adımı korunma basamağı oluşturmaktadır. Alınması gereken başlıca önlemler; kalabalık ortamlara girmemek, girilmesi gerektiğinde en az 1,5 m olan sosyal mesafeyi korumak, hasta kişiler ile temastan kaçınmak ve el yıkamaktır. El hijyeninde en az \%60 oranında alkol içeren dezenfektanlar tercih edilmeli ve görünür kirlilik halinde de mutlaka su ve sabun ile en az 20 sn boyunca yıkanmalıdır (52).

Alınabilecek mekanik önlemlerin dışında aşı ile korunmanın da mümkün olduğu öngörülmektedir. Haziran 2020 itibariyle preklinik aşamada 132, klinik aşamada 17 adet aday aşı çalışılması yürütülmektedir. Bunların içerisinden sadece bir tanesi Faz 3 aşamasına geçebilmeyi başarmıştır (53).

Tüm yaş gruplarını etkileyen bu enfeksiyon hastalığı her geçen gün daha çok bireyin enfekte olmasına ve daha çok bireyin hayatını kaybetmesine yol açmaktadır. Yürütülen aşı çalışmalarından yüz güldürücü bir sonuç elde edilinceye kadar korunma önlemlerinin en önemli halkayı oluşturduğu asla unutulmamalıdır. 
Hakem Değerlendirmesi: Dış bağımsız.

Yazar Katkıları: Çalışma Konsepti/Tasarım- Ö.K., A.S.; Veri ToplamaÖ.K., A.S.; Veri Analizi/Yorumlama- Ö.K., A.S.; Yazı Taslağı-Ö.K.; İçeriğin Eleştirel İncelemesi- A.S.; Son Onay ve Sorumluluk- Ö.K., A.S.; Malzeme ve Teknik Destek- Ö.K., A.S.; Süpervizyon-A.S.

Çıkar Çatışması: Yazarlar çıkar çatışması beyan etmemişlerdir.

Finansal Destek: Yazarlar finansal destek beyan etmemişlerdir.

Peer Review: Externally peer-reviewed.

Author Contributions: Conception/Design of Study- Ö.K., A.S; Data Acquisition- Ö.K., A.S.; Data Analysis/Interpretation- Ö.K., A.S.; Drafting Manuscript-Ö.K.; Critical Revision of Manuscript- A.S.; Final Approval and Accountability- Ö.K., A.S.; Technical or Material Support- Ö.K., A.S.; Supervision- A.S.

Conflict of Interest: Authors declared no conflict of interest.

Financial Disclosure: Authors declared no financial support.

\section{KAYNAKLAR/REFERENCES}

1. Beaudette FR, Hudson CB. Cultivation of the virus of infectious bronchitis. J Am Vet Med Assoc 1937;90:51-8.

2. Ogimi C, Kim YJ, Martin ET, Huh HJ, Chiu CH, Englund JA. What's new with the old coronaviruses? J Pediatr Infect Dis Soc 2020;9(2):21017. doi:10.1093/jpids/piaa037

3. Englund J, Kim Y, Mclntosh K. Human coronaviruses, including Middle East respiratory syndrome coronavirus. In: Feigin and Cherry's Textbook of Pediatric Infectious Diseases [Internet]. 8th ed. Philadelphia, PA: Elsevier; 2019. [1 online resource (xxvi, 2696)]. Available at: Clinical Key https://www.clinicalkey.com/dura/browse/ bookChapter/3-s2.0- C20141033200. AccessedFebruary 10, 2020.

4. Lu R, Zhao X, Li J, et al. Genomic characterization and epidemiology of 2019 novel coronavirus: implications for virus origins and receptor binding. Lancet 2020;395:565-74.

5. World Health Organization. Director-General's remarks at the media briefing on 2019- nCoV on 11 February 2020. https://www. who.int/dg/speeches/detail/who-director-general- s-remarks-atthe-media-briefing-on-2019-ncov-on-11-february-2020 (Accessed on May 28, 2020.)

6. Chan JF, Yuan S, Kok KH, To KK, Chu H et al. A familial cluster of pneumonia associated with the 2019 novel coronavirus indicating person-to-person transmission: a study of a family cluster. Lancet 2020;395:514-23. doi: 10.1093/infdis/jiaa077

7. World Health Organization (WHO). WHO Director-General's opening remarks at the media briefing on COVID-19 11 March 2020. Available from: https://www.who.int/dg/speeches/detail/ who-director-general-s-opening-remarks-at-the- media-briefingon-covid-19---11-march-2020 (Accessed on May 28, 2020.)

8. World Health Organization (WHO). Emergencies, Diseases, Coronavirus disease 2019. Available from https://www.who.int/emergencies/ diseases/novel-coronavirus-2019. (Accessed on May 28, 2020.)

9. Zhou P, Yang XL, Wang XG, et al. A pneumonia outbreak associated with a new coronavirus of probable bat origin. Nature 2020;579:270.

10. Shereen MA, Khan S, Kazmi A, et al. COVID-19 Infection: Origin, Transmission, and Characteristics of Human Coronaviruses. J Adv Res 2020;24:91.
11. Gorbalenya AE, Baker SC, Baric RS, et al. Severe acute respiratory syndrome-related coronavirus: The species and its viruses a statement of the Coronavirus Study Group. bioRxiv 2020. https://www.biorxiv.org/content/10.1101/2020.02.07.937862v1 (Accessed on February 12, 2020).

12. Zou X, Chen K, Zou J, Han P, Hao J, Han Z. Single-cell RNA-seq data analysis on the receptor ACE2 expression reveals the potential risk of different human organs vulnerable to 2019-nCoV infection. Front Med 2020;14(2):185-192. doi:10.1007/s11684-020-0754-0

13. Li W, Moore MJ, Vasilieva N, et al. Angiotensin-converting enzyme 2 is a functional receptor for the SARS coronavirus. Nature 2003;426(6965):450-454. doi:10.1038/nature02145

14. Yuki K, Fujiogi M, Koutsogiannaki S. COVID-19 pathophysiology: A review. Clin Immunol 2020;215:108427. doi:10.1016/j. clim.2020.108427

15. Bautista-Vargas M, Bonilla-Abadía F, Cañas CA. Potential role for tissue factor in the pathogenesis of hypercoagulability associated with in COVID-19 [published online ahead of print, 2020 Jun 9]. J Thromb Thrombolysis 2020;1-5. doi:10.1007/s11239-020-02172-x

16. Mehta P, McAuley DF, Brown M, et al. COVID-19: consider cytokine storm syndromes and immunosuppression. Lancet 2020;395(10229):1033-1034. doi: 10.1016/S0140-6736(20)30628-0

17. Palmeira P, Barbuto JAM, Silva CAA, Carneiro-Sampaio M. Why is SARS-CoV-2 infection milder among children? Clinics (Sao Paulo) 2020;75:e1947. doi:10.6061/clinics/2020/e1947

18. Cao $Q$ et al., SARS-CoV-2 infection in children: Transmission dynamics and clinical characteristics, Journal of the Formosan Medical Association, https://doi.org/10.1016/j.jfma.2020.02.009

19. World Health Organization (2020). Modes of transmission of virus causing COVID-19: implications for IPC precaution recommendations. Scientific brief. 29 March 2020 [online]. Available from https://www.who.int/news-room/commentaries/ detail/modes-oftransmission-of-virus-causing-covid-19implications-for-ipc-precaution- recommendations [accessed 29 June 2020].

20. D'Amico F, Baumgart DC, Danese S, Peyrin-Biroulet L. Diarrhea during COVID-19 infection: pathogenesis, epidemiology, prevention, and management [published online ahead of print, 2020 Apr 8]. Clin Gastroenterol Hepatol. 2020;S15423565(20)30481-X. doi:10.1016/j.cgh.2020.04.001

21. Schwartz DA. An analysis of 38 pregnant women with COVID-19, their newborn infants, and maternal-fetal transmission of SARSCoV-2: maternal coronavirus infections and pregnancy outcomes. Archives of Pathology and Laboratory Medicine 2020. doi: 10.5858/arpa.2020-0901-SA.

22. Li Q, Guan X, Wu P, et al. Early transmission dynamics in Wuhan, China, of novel coronavirus-infected pneumonia. N Engl J Med 2020; 382:1199.

23. Lauer SA, Grantz KH, Bi Q, et al. The incubation period of coronavirus disease 2019 (COVID-19) from publicly reported confirmed cases: Estimation and application. Ann Intern Med 2020;172(9):577-82. doi:10.7326/M20-0504

24. Shin KS, Park HS, Lee J, Lee JK. Environmental surface testing for severe acute respiratory syndrome coronavirus 2 (SARS-CoV-2) during prolonged isolation of an asymptomatic carrier [published online ahead of print, 2020 Jun 16]. Infect Control Hosp Epidemiol. 2020;1-9. doi:10.1017/ice.2020.300 
25. Kampf G, Todt D, Pfaender S, Steinmann E. Persistence of coronaviruses on inanimate surfaces and their inactivation with biocidal agents. J Hosp Infect 2020;104(3):246-251. doi:10.1016/j. jhin.2020.01.022.

26. Oran DP, Topol EJ. Prevalence of asymptomatic SARS-CoV-2 infection: A narrative review [published online ahead of print, 2020 Jun 3]. Ann Intern Med. 2020;M20-3012. doi:10.7326/M20-3012

27. Ludvigsson JF. Systematic review of COVID-19 in children shows milder cases and a better prognosis than adults. Acta Paediatr 2020;109:1088.

28. United States Centers for Disease Control and Prevention. Cases in the US. Available at: https://www.cdc.gov/coronavirus/2019-ncov/ cases-updates/cases-in-us.html (Accessed on June 17, 2020).

29. CDC COVID-19 Response Team. Coronavirus disease 2019 in children - United States, February 12-April 2, 2020. MMWR Morb Mortal Wkly Rep 2020;69:422.

30. Price-Haywood EG, Burton J, Fort D, Seoane L. Hospitalization and mortality among Black patients and White patients with Covid-19. N Engl J Med 2020.

31. Parri N, Lenge M, Buonsenso D, Coronavirus Infection in Pediatric Emergency Departments (CONFIDENCE) Research Group. Children with Covid-19 in Pediatric Emergency Departments in Italy [published online ahead of print, 2020 May 1]. N Engl J Med 2020;NEJMc2007617. doi:10.1056/NEJMc2007617

32. Tong JY, Wong $A$, Zhu $D$, et al. The prevalence of olfactory and gustatory Dysfunction in COVID-19 Patients: A systematic review and meta-analysis. Otolaryngol Head Neck Surg 2020;163(1):3-11. doi:10.1177/0194599820926473

33. Dong $\mathrm{Y}, \mathrm{Mo} \mathrm{X}, \mathrm{Hu} \mathrm{Y}$, et al. Epidemiology of COVID-19 among children in China [published online ahead of print, 2020 Mar 16]. Pediatrics 2020;e20200702. doi:10.1542/peds.2020-0702

34. Galván Casas C, Català A, Carretero Hernández G, et al. Classification of the cutaneous manifestations of COVID-19: a rapid prospective nationwide consensus study in Spain with 375 cases. Br J Dermatol 2020;183(1):71-7. doi:10.1111/bjd.19163

35. Manalo IF, Smith MK, Cheeley J, Jacobs R. A dermatologic manifestation of COVID-19: Transient livedo reticularis. J Am Acad Dermatol 2020;50190-9622(20)30558-2. doi:10.1016/j. jaad.2020.04.018

36. Madigan LM, Micheletti RG, Shinkai K. How Dermatologists Can Learn and Contribute at the Leading Edge of the COVID-19 Global Pandemic. JAMA Dermatol 2020;10.1001/jamadermatol. 2020.1438. doi:10.1001/jamadermatol.2020.1438

37. Zheng YY, Ma YT, Zhang JY, Xie X. COVID-19 and the cardiovascular system. Nat Rev Cardiol 2020; 17:259.

38. World Health Organization, Newsroom, Commentaries, Detail, Scientific Brief: Multisystem inflammatory syndrome in children and adolescents temporally related to COVID-19. Available from: https://www.who.int/news- room/commentaries/ detail/multisystem-inflammatory-syndrome-in-children-andadolescents-with-covid-19 (Accessed on June 24, 2020).

39. T. C. Sağlık Bakanlığı, Halk Sağlığı Genel Müdürlüğü, COVID-19, Yeni Koronavirus Hastalığı, Rehberler, Çocuk Hasta Yönetimi ve Tedavisi, 3 Haziran 2020. Available from https://covid19bilgi. saglik.gov.tr/depo/rehberler/covid-19-rehberi/COVID-19_ REHBERI_COCUK_HASTA_YONETIMI_VE_TEDAVI.pdf. Accessed on June 24, 2020.
40. Lieberman JA, Pepper G, Naccache SN, et al. Comparison of commercially available and laboratory developed assays for in vitro detection of SARS-CoV-2 in clinical Laboratories. J Clin Microbiol 2020;JCM.00821-20. doi:10.1128/JCM.00821-20

41. Long DR, Gombar S, Hogan CA, et al. Occurrence and timing of subsequent SARS-CoV-2 RT-PCR positivity among initially negative patients. Clin Infect Dis 2020;ciaa722. doi:10.1093/cid/ciaa722

42. Cheng MP, Yansouni CP, Basta NE, et al. Serodiagnostics for Severe Acute Respiratory Syndrome-Related Coronavirus-2: A narrative review. Ann Intern Med 2020;M20-2854. doi:10.7326/M20-2854

43. US Food and Drug Administration Statement: Coronavirus (COVID-19) Update: FDA Authorizes First Antigen Test to Help in the Rapid Detection of theVirus that Causes COVID-19 in Patients. https://www.fda.gov/news-events/press- announcements/ coronavirus-covid-19-update-fda-authorizes-first-antigen-testhelp-rapid- detection-virus-causes (Accessed on June 29, 2020).

44. ACR Recommendations for the use of Chest Radiography and Computed Tomography (CT) for Suspected COVID-19 Infection https://www.acr.org/Advocacy-and- Economics/ACR-PositionStatements/Recommendations-for-Chest-Radiography-and-CTfor-Suspected-COVID19-Infection (Accessed on June 26, 2020).

45. Bao C, Liu X, Zhang H, et al. Coronavirus Disease 2019 (COVID-19) CT findings: A systematic review and meta-analysis. J Am Coll Radiol 2020;17:701.

46. Goyal P, Choi JJ, Pinheiro LC, et al. Clinical characteristics of Covid-19 in New York city. N Engl J Med 2020;382:2372.

47. Henry BM, de Oliveira MHS, Benoit S, Plebani M, Lippi G. Hematologic, biochemical and immune biomarker abnormalities associated with severe illness and mortality in coronavirus disease 2019 (COVID-19): a meta-analysis. Clin Chem Lab Med 2020;58(7):1021-28. doi:10.1515/cclm-2020-0369

48. US FDA. Remdesivir letter of EUA. https://www.fda.gov/ media/137564/download (Accessed on June 29, 2020).

49. US FDA. Coronavirus (COVID-19) Update: FDA revokes emergency use authorization for chloroquine and hydroxychloroquine. June 15, 2020. https://www.fda.gov/news-events/press-announcements/ coronavirus-covid-19-update-fda-revokes-emergency-useauthorization-chloroquine-and (Accessed on June 29, 2020).

50. Xu Z, Shi L, Wang Y, et al. Pathological findings of COVID-19 associated with acute respiratory distress syndrome [published correction appears in Lancet Respir Med 2020 Feb 25;:]. Lancet Respir Med 2020;8(4):420-422. doi:10.1016/S2213-2600(20)30076-X

51. Tezer H, Bedir Demirdağ T. Novel coronavirus Disease (COVID-19) in children. Turk J Med Sci 2020;50:592-603.

52. T. C. Sağlık Bakanlığı, Halk Sağlığı Genel Müdürlüğü, Koronavirus, COVID-19 Yeni Koronavirus Hastalığı, COVID-19 Rehberi, Genel Bilgiler, Epidemiyoloji ve Tanı, Ankara, 29 Haziran 2020. Available from https://covid19bilgi.saglik.gov.tr/depo/rehberler/covid-19rehberi/COVID-19_REHBERI_GENEL_BILGILER_EPIDEMIYOLOJI_ VE_TANI.pdf. Accessed on June 29, 2020.

53. World Health Organization, Health Topics, Coronavirus disease (COVID-19), Research and Guidance, Global Research, Update on WHO Solidarity Trial-Accelerating a safe anf effective COVID-19 vaccine, Draft landscape of COVID-19 candidate vaccines. Available from https://www.who.int/who-documents-detail/draftlandscape-of-covid-19-candidate-vaccines. Accessed on 29 June 2020. 